\title{
PERANAN MANAJER PENDIDIKAN PERSPEKTIF PENDIDIKAN ISLAM
}

\author{
Al-Irsyadiyah \\ mrsalirsyadiyah@gmail,com \\ (Fakultas Agama Islam, Universitas Muhammadiyah Tangerang)
}

\begin{abstract}
Abstrak:
Manajer perlu memiliki Pengetahuan luas, kreatif, inisiatif, peka, dan lapang dada. Bertindak adil, jujur serta konsekuen. Bertanggung Jawab, Selektif terhadap informasi. Memberi petunjuk dan pengarahan. Peranan yang dimilikinya; Memberikan semangat bekerja seefektif dan seefisien mungkin. Mengembangkan perencanaan capaian kinerja. Memperhatikan intern, ekstern yang dihadapkan pada lembaga. Memiliki kemampuan merespon, teliti, tepat sasaran dalam menanggapi sesuatu yang dapat menguntungkan atau merugikan lembaga pendidikan. Menikmati hasil yang diperoleh dengan berpegang pada etika dan nilai-nilai kelembagaan. Mewujudkan proses pembelajaran aktif, inovatif, kreatif, efektif. Menciptakan peserta didik yang mampu mengembangkan kekuatan spiritual, pengendalian diri, kepribadian, kecerdasan, akhlak mulia, dan keterampilan dirinya, masyarakat, dan negara. Menciptkan hubungan harmonis, terfokus dalam kerja sama antar bidang pada lembaga pendidikan. Melaporkan hasil kinerja kemudian ditindaklanjuti dengan pembagian tugas imbang sesuai dengan porsi masing-masing. Sebagai pembangun nilai-nilai organisasi sehingga akan memunculkan sosok sebagai contoh.
\end{abstract}

\section{Kata Kunci: Peranan, Manajer, Pendidikan Islam.}

\begin{abstract}
:
Managers need to have broad knowledge, be creative, initiative, sensitive, and generous. Act fairly, honestly and consequently. Responsible, selective about information. Give directions and direction. The role it has; Give enthusiasm to work as effectively and efficiently as possible. Develop a performance achievement plan. Paying attention to the internal, external to the institution. Having the ability to respond, thorough, right on target in responding to something that can benefit or harm educational institutions. Enjoy the results obtained by adhering to ethical and institutional values. Realizing an active, innovative, creative, effective learning process. Creating students who are able to develop spiritual strength, self-control, personality, intelligence, noble character, and skills for themselves, society and the country. Creating harmonious relationships, focused on cooperation between fields in educational institutions. Reporting the results of the performance is then followed up with a balanced division of tasks according to each portion. As a builder of organizational values so that a figure will emerge as an example.
\end{abstract}

Keywords: Role, Manager, Islamic Education.

\section{A. Pendahuluan}

Melalui pendidikan, semua potensi yang terdapat pada setiap individu dikembangkan secara maksimal agar individu dapat menjadi manusia yang beriman dan bertaqwa kepada Tuhan Yang Maha Esa, berakhlak mulia, sehat, berilmu, cakap, kreatif, mandiri, dan menjadi 
warganegara yang demokratis serta bertanggung jawab. ${ }^{1}$

Kepemimpinan/Manajer suatu proses untuk menggerakkan sekelompok orang menuju suatu tujuan yang telah di sepakati berasama dengan mendorong atau memotivasi untuk bertindak dengan tidak terpaksa. Dengan kemampuan seorang pemimpin yang baik dapat menggerakkan orang-orang menuju tujuan jangka panjang dan betul-betul merupakan usaha untuk memenuhi kepentingan mereka. ${ }^{2}$

Pada tataran konseptual, manajemen sekolah yang berhasil akan mampu menciptakan peserta didik dengan prestasi yang baik dan akhlak yang mulia. Dalam konteks ajaran Islam, manajemen pendidikan Nabi Muhammad Saw telah terbukti dalam sejarah sebagai manajemen yang efektif. Menurut Ahmad Abdul Jawwad, terdapat enam keunggulan manajemen Rasulullah SAW, yaitu: 1) kemampuan motivasi tim, 2) simple dalam motivasi, 3) kemampuan berkomunikasi, 4) kemampuan mendelegasi dan membagi tugas, 5) efektif dalam memimpin rapat, 6) kemampuan mengawasi dan mengevaluasi. ${ }^{3}$

Faktor yang mengharuskan upaya perbaikan manajemen pendidikan Islam adalah Pemimpin/manajer yang dapat melaksanakan tugas kepemimpinannya secara efektif dapat menggerakkan orang atau bawahannya ke arah tujuan yang diinginkannya, dan akan menjadi anutan dan teladan. Begitu pula sebaliknya, pemimpin yang keberadaannya hanya sebagai figur dan tidak memiliki pengaruh serta kemampuan kepemimpinan, akan

${ }^{1}$ UU No. 20 Tahun 2003 Tentang Sistem Pendidikan Nasional Bab II Pasal 3, Jakarta: Balitbang, Depdiknas 2004.

${ }^{2}$ Veithza Rivai, Kiat Memimpin Abad 21, (Jakarta: PT Raja Grafindo,2004).h.64

${ }^{3}$ Abdul Jawwad, M. Ahmad, Manajemen Waktu, (terjemahan Khozin Abu Faqih). Bandung: Syaamil Cipta Media, 2006, h. 1 mengakibatkan kinerja organisasi tersebut menjadi lambat. Karena pemimpin tersebut tidak memiliki kapabilitas dan kecakapan untuk menghasilkan kinerja yang baik. Betapa penting dan berartinya peranan manajer pendidikan, dalam mendesain sebuah masyarakat, bangsa dan negara.

\section{B. Metodelogi Penelitian}

Penelitian ini menggunakan jenis penelitian kualitatif yaitu suatu metode penelitian yang digunakan untuk meneliti pada kondisi obyek yang alamiah, dimana peneliti adalah sebagai instrument kunci. Pendekatan dalam Penelitian ini menggunakan analisis deskriptif kualitatif. Adapun teknik pengumpulan data, selain studi pustaka, observasi, diskusi, dan juga menggunakan analisis data melalui penelaahan yang dilakukan secara intensif, mendetail, dan komprehensif.

\section{Hasil Penelitian dan Pembahasan}

\section{Karakteristik Manajer Pendidikan Perspektif Pendidikan Islam}

Agar tujuan pendidikan Islam bisa dicapai sesuai dengan yang diharapkan maka diperlukan adanya manajer /kepemimpinan yang handal yang mampu membuat perencanaan yang baik, mengorganisir, menggerakkan, dan melakukan kontrol serta tahu kekuatan, kelemahan, peluang, dan ancaman, maka orang yang diberi amanat dalam memanaj lembaga pendidikan Islam perlu memiliki kompetensi sesuai dengan tuntunan AlQur'an, menurut Tanthowi kompetensi tersebut antara lain:

1) Berpengetahuan luas, kreatif, inisiatif, peka, dan lapang dada. Hal ini sesuai dengan QS. al-Mujadalah[58];11,

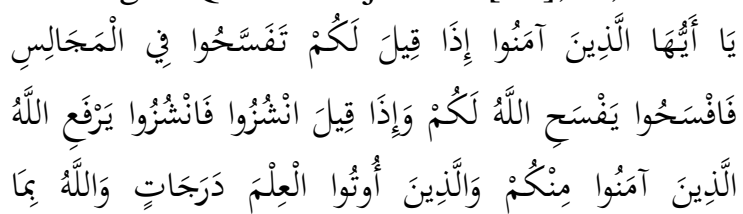




$$
\text { تَعْمَلُونَ خَبِيرٌ (11) }
$$

Hai orang-orang beriman apabila kamu dikatakan kepadamu: "Berlapanglapanglah dalam majlis", Maka lapangkanlah niscaya Allah akan memberi kelapangan untukmu. dan apabila dikatakan: "Berdirilah kamu", Maka berdirilah, niscaya Allah akan meninggikan orang-orang yang beriman di antaramu dan orang-orang yang diberi ilmu pengetahuan beberapa derajat. dan Allah Maha mengetahui apa yang kamu kerjakan.

2) Bertindak adil dan jujur serta konsekuen. Hal ini sesuai dengan QS. al-Nisa[4]: 58:

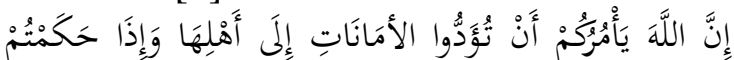

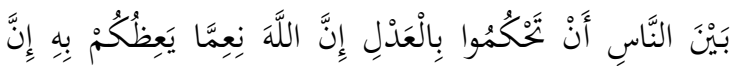

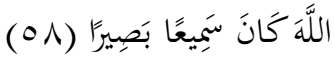

Sesungguhnya Allah menyuruh kamu menyampaikan amanat kepada yang berhak menerimanya, dan (menyuruh kamu) apabila menetapkan hukum di antara manusia supaya kamu menetapkan dengan adil. Sesungguhnya Allah memberi pengajaran yang sebaik-baiknya kepadamu. Sesungguhnya Allah adalah Maha mendengar lagi Maha Melihat.

3) Bertanggung Jawab. Sesuai dengan QS. al-An'am[6]: 164;

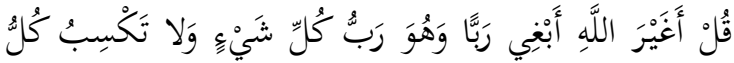

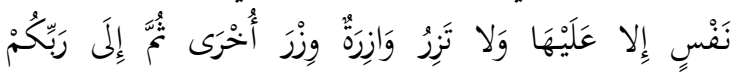

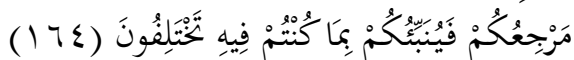

Katakanlah: "Apakah Aku akan mencari Tuhan selain Allah, padahal dia adalah Tuhan bagi segala sesuatu. dan tidaklah seorang membuat dosa melainkan kemudharatannya kembali kepada dirinya sendiri; dan seorang yang berdosa tidak akan memikul dosa orang lain. Kemudian kepada Tuhanmulah kamu kembali, dan akan diberitakan-Nya kepadamu apa yang kamu perselisihkan."

4) Selektif terhadap informasi. Sesuai dengan QS. al-Hujurat[49]: 6:

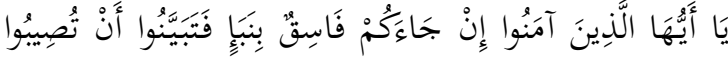

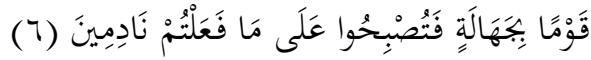

Hai orang-orang yang beriman, jika datang kepadamu orang fasik membawa suatu berita, Maka periksalah dengan teliti agar kamu tidak menimpakan suatu musibah kepada suatu kaum tanpa mengetahui keadaannya yang menyebabkan kamu menyesal atas perbuatanmu itu.

Memberi Peringatan. Sesuai QS. alDzariat[51]: 55.

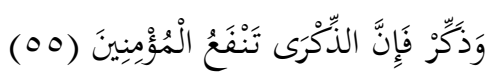

Dan tetaplah memberi peringatan, Karena Sesungguhnya peringatan itu bermanfaat bagi orang-orang yang beriman.

5) Memberi petunjuk dan pengarahan.

Sesuai dengan QS. al-Sajdah[32]: 24;

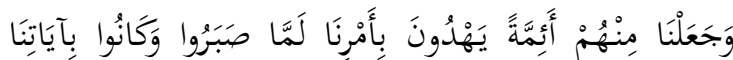

$$
\text { يُوقِنُونَ (T\&) }
$$

Dan kami jadikan di antara mereka itu pemimpin-pemimpin yang memberi petunjuk dengan perintah kami ketika mereka sabar. dan adalah mereka meyakini ayat-ayat kami.

Selain memiliki kompetensi diatas juga dipelukan memiliki teladan yang menjadi model ideal pemimpin(QS. AlAhzab:21), Rasulullah dikaruniai empat sifat utama, yaitu: Sidiq, Amanah, Tablig dan Fathonah. Sidiq berarti jujur dalam perkataan dan perbuatan, amanah berarti dapat dipercaya dalam menjaga tanggung jawab, Tablig berarti menyampaikan segala macam kebaikan kepada rakyatnya dan fathonah berarti cerdas dalam mengelola.

Mengenai empat sifat utama diatas ada yang menarik mengenai nilai amanah, Daniel Goleman mencatat beberapa ciri orang yang memiliki sifat tersebut.

a. Dia bertindak berdasarkan etika dan tidak pernah mempermalukan orang 
b. Membangun kepercayaan diri lewat keandalan diri dan autentisitas (kemurnia/kejujuran)

c. Berani mengakui kesalahan sendiri dan berani menegur perbuatan tidka etis ornag lain

d. Berpegang kepada prinsip secara teguh, walaupun resikonya tidak disukai serta memiliki komitmen dan menepati janji

e. Bertangung jawab sendiri untuk memperjuangkan tujuan serta terorganisir dan cermat dalam bekerja. (Goleman, 1998) ${ }^{4}$

\section{Peranan Manajer Pendidikan Perspektif Pendidkan Islam}

Peran manajer pendidikan dalam upaya peningkatan mutu program adalah memastikan bahwa adalah terwujudnya keseluruhan program kerja secara efektif dan efisien. ${ }^{5}$ Dengan kata lain dengan adanya manajer yang unggul maka kinerja lembaga bisa berjalan tepat sasaran atau personalia lembaga bertindak sesuai dengan tujuan, sehingga menghasilkan 'sesuatu' yang sebaik-baiknya. Dan pula di sisi lain dengan adanya manajemen yang kokoh maka akan menghasilkan kinerja yang dilakukan dengan tepat waktu, tepat pemanfaatan sumber daya yang dimiliki, dan tepat pembiayaan (efisien) sehingga bisa mencegah terjadinya in-efisiensi.

Peranan manajer pendidikan terkait kinerjanya menurut Syaefullah yaitu:

1) Memberikan semangat agar bekerja seefektif dan seefisien mungkin.

2) Mengembangkan perencanaan beserta capaian kinerja manajer memperhatikan keadaan intern dan ekstern yang dihadapkan pada lembaga.

\footnotetext{
${ }^{4}$ Toto Tasmara, Spiritual Centered

Leadership, h. 124

${ }^{5}$ Ibrahim Bafadal. Seri Manajemen Peningkatan Mutu Pendidikan Berbasis Sekolah. Jakarta: Bumi Aksara, 2009.h. 50.
}

3) Memiliki kemampuan merespon dengan cepat, teliti, dan tepat sasaran dalam menanggapi segala sesuatu yang dapat menguntungkan atau merugikan lembaga pendidikan.

4) Menikmati hasil yang diperoleh dengan berpegang pada etika dan nilai-nilai kelembagaan.

5) Mewujudkan proses pembelajaran yang aktif, inovatif, kreatif, efektif, dan menyenangkan.

6) Menciptakan peserta didik yang mampu mengembangkan dirinya yang mempunyai kekuatan spiritual, pengendalian diri, kepribadian, kecerdasan, akhlak mulia, dan keterampilan yang diperlukan oleh dirinya, masyarakat, dan negara. ${ }^{6}$

7) Menciptkan suasana hubungan harmonis dan terfokus dalam kerja sama antar bidang serta intern bidang pada lembaga pendidikan.

8) Melaporkan hasil kinerja kemudian ditindaklanjuti dengan pembagian tugas yang imbang sesuai dengan porsi (gaji) masing-masing.

9) Sebagai pembangun nilai-nilai dalam organisasi sehingga akan memunculkan sosok tertentu sebagai contoh (kemampuan interpersonal). ${ }^{7}$

Mulyono menjelaskan peran manajer pendidikan dalam pengembangan setiap aspek yang terdapat dalam program kerja pendidikan, terutama adanya tanggung jawab, penjaga nilai-nilai organisasi, pembagian kerja, dan efisiensi. Terdapat banyak ayat atau beberapa dalil al Qur'an yang memiliki makna yang tak jauh berbeda dengan mengelaborasi peran-peran manajemen dalam pengembangan tiap aspek pendidikan yaitu sebagai berikut: ${ }^{8}$

${ }^{6}$ Husaini Usman. Manajemen: Teori, Praktik, dan Riset Pendidikan. Jakarta: Bumi Aksara, 2008. h. 10.

${ }^{7}$ Saefullah. Manajemen Pendidikan Islam, (Bandung: Pustaka Setia), 2012. h. 7-8.

${ }^{8}$ Mulyono. Manajemen Administrasi \& 
1. Bertanggung jawab

2. Penjaga nilai-nilai organisasi

3. Pembagian tugas dan tanggung jawab

1) Bertanggung Jawab

Ayat Al-Quran, terkait dengan tanggung jawab adalah QS. al-Zalzalah [99]:6-7

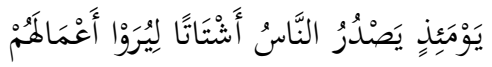

Barangsiapa yang mengerjakan kebaikan seberat dzarrahpun, niscaya dia akan melihat (balasan)nya.

$$
\text { فَمَنْ يَعْمَلْ مِنْقَلَ ذَرَّةٍ خَيْرَا يَرَهُ }
$$

Dan barangsiapa yang mengerjakan kejahatan sebesar dzarrahpun, niscaya dia akan melihat (balasan)nya pula

Banyak ayat al-Qur'an yang melarang manusia untuk menyia-nyiakan waktu, menganggap enteng pekerjaan yang kecil, karena dianggap tidak signifikan, atau menganggap remeh peranperan yang sederhana, padahal apapun yang dikerjakan oleh seorang, meskipun pekerjaannya tersebut sebesar inti atom, dimata Allah SWT ada maknanya dan akan mendapatkan imbalan setimpal. Dengan kata setiap aktivitas atau kegiatan, dan tindakan yang dilakukan seseorang dalam satu organisasi harus selaras dan mendukung sesuai pencapaian tujuan organisasi.

Begitu pula seseorang dalam organisasi pendidikan harus melakukan melakukan tindakan semaksimal mungkin dalam mewujudkan tujuan sesui dengan masing-masing bidang atau tiap aspek pendidikan yang dia emban. Jika dilakukan secara setengah-setengah maka itu adalah sebuah tindakan yang dianggap 'kecil' tapi juga akan memperoleh balasan yang setimpal pula, QS. al-Thur 21:

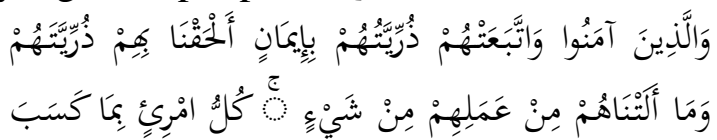

Organisasi Pendidikan, Yogyakarta: Ar-Ruzz Media, 2009, h. 29-30
Dan orang-oranng yang beriman, dan yang anak cucu mereka mengikuti mereka dalam keimanan, Kami hubungkan anak cucu mereka dengan mereka, dan Kami tiada mengurangi sedikitpun dari pahala amal mereka. Tiap-tiap manusia terikat dengan apa yang dikerjakannya.

2) Penjaga Nilai-nilai Organisasi

Nilai merupakan sesuatu yang sulit untuk digambarkan secara konkrit, karena nilai adalah sebuah tatatan sistem yang ideal terbangun secara reflek tingkah laku personal organisasi maupun penghayatan yang didesain. Sehingga bisa dinyatakan bahwa nilai adalah internalisasi antara keyakinan, perasaan, dan kemantapan yang menjadi identitas khusus terhadap pola pemikiran, hubungan, dan perilaku. ${ }^{9}$

Dari pernyataan tersebut maka penulis dapat mengambil inti utamanya bahwa nilai dapat menjadi dasar atau pijakan personal organisasi dalam bertindak. Setiap tindakan yang selalu berdasarkan pada nilai-nilai yang telah dibangun tersebut maka lama kelamaan akan menjadi sebuah budaya yang tercermin pada perilaku personalia lembaga pendidikan. Setiap perilaku atau kegiatan positif personalia yang berdasarkan nilai-nilai yang telah ditetapkan maka akan menghasilkan karya berwujud benda maupun jasa yang sesuai dengan tujuan lembaga pendidikan. Karena nilai-nilai organisasi terbentuk dengan adanya pengumpulan aktivitas dalam jangka waktu lama, kemudian terinternalisasi menjadi kebiasaan yang tercermin dalam pergaulan dan kehidupan sehari-hari. Sedangkan pendesainan nilainilai organisasi sering kali terbentuk oleh ketetapan-ketetapan berupa slogan, visi,

${ }^{9}$ M. Asrori Ardiansyah. "Pengertian Nilai," dalam http: //www .majalahpendidikan.com/ 2011 /04/p engertian-nilai.html, diakses pada tanggal 16 Januari 2013. 
dan motto dalam sistem manajerial yang telah ditetapkan organisasi.

Lebih dari pada itu nilai-nilai organisasi menjadi pedoman bagi setiap personal lembaga pendidikan untuk tercapainya suasana atau iklim yang nyaman, aman, tertib, bertanggung jawab, profesional, harmonis, dan kondusif. ${ }^{10}$ Suasana yang kodusif seperti itu bukanlah sebuah tujuan bagi organisasi tapi merupakan salah satu cara bagaimana agar sistem rotasi organisasi bisa berjalan dengan lancar dan berfungsi dengan tepat sehingga bisa tercapai tujuan lembaga pendidikan dengan cara dan hasil yang sempurna. Nilai-nilai organisasi sebagai intangible asset memiliki peran penting bahkan utama. Karena berdasarkan penelitian menunjukkan bahwa adanya pergeseran pandangan tentang lebih bermaknanya intangible asset dari padatangible asset dalam organisasi. $^{11}$

Dengan demikian bahwa fungsi nilainilai organisasi (intangible asset) bagi proses pengembangan lembaga pendidikan adalah sebagai 'kunci utama' berjalannya organisasi secara tersistem (tidak berjalan sendiri-sendiri). Organisasi yang memiliki intangible assetakan menjadi organisasi berperforma nilai tinggi yang memiliki anggota menyatu, proseional, dan penuh semangat yang tidak bersifat semu atau sementara.

Sehingga wajar jika ada sebuah organisasi memiliki 'harga' tinggi di mata masyarakat karena memiliki intagible asset yang unggul walaupun aset (sumber daya) secara kasat mata tidak begitu mencolok. Dengan kata lain adanya intageible asset yang unggul pada lembaga pendidikan maka akan bisa menciptakan

\footnotetext{
${ }^{10}$ Mulyasa. Manajemen dan Kepemimpinan Kepala Sekolah, Jakarta: Bumi Aksara, 2011, h. 90.

${ }^{11}$ Mulyasa Manajemen Dan Kepemimpinan Kepala Sekolah. Jakarta: Bumi Aksara, 2011. h. 92.
}

produk layanan yang unggul pula misalnya meningkatnya prestasi siswa, terjadinya perubahan perilaku siswa yang semakin positif, dan hasil positif lainnya yang akan berdampak pada peningkatan mutu pendidikan.

Menurut Rohiat yang ia kutip dari Massie ada sejumlah nilai yang pada umumnya semuanya dapat diterima dan dipahami dalam setiap aspek manajemen. Dianataranya adalah kebahagiaan, ketaatan pada hukum, konsistensi, integritas, dan kesetiaan. Menurutnya dengan terpenuhinya kebahagiaan maka setiap personal lembaga akan melakukan kegiatan dengan sepenuh hati tanpa beban atau tertekan sehingga setiap langkah dan tutur katanya merupakan keringanan dicurahkan kepada lembaga sebagai balas budi karena lembaga/pimpinan 'memberikan' kebahagiaan. ${ }^{12}$

Nilai-nilai yang dikembangkan dalam lembaga pendidikan tidak lepas dari keberadaannya sebagai organisasi pendidikan yang memiliki peran dan fungsi untuk menumbuh kembangkan, melestarikan, dan mewariskan nilai-nilai kepada siswanya. ${ }^{13}$

Sehingga nilai-nilai tersebut juga bisa berfungsi untuk membangun citra lembaga pendidikan di mata masyarakat. Secara teknis cara memfungsingkan nilai-nilai organisasi agar menjadi motivasi dan landasan kerja seluruh civitas lembaga pendidikan adalah manajer atau orang yang berpengaruh baik dari internal maupun eksternal, baik secara langsung maupun tidak langsung memberi contoh serta menjadi pengayom dalam penerapan nilainilai organisasi tersebut. Selanjutnya orang-orang yang menjadi figur utama

\footnotetext{
${ }^{12}$ Rohiat, Manajemen Sekolah: Teori dan Praktik, Bandung: Refika Aditama, 2010, h. 4.

${ }^{13}$ Nur Zazin. Gerakan Menata Mutu Pendidikan, Jogjakarta: Ar-Ruzz Media, 2011, h. 155
} 
dalam lembaga pendidikan menanamkan doktrin secara verbal maupun non verbal yaitu dengan kata-kata atau tulisan (tekstual) maupun dengan bentuk ajakan yang bersifat kontekstual, menamakan kepercayaan, menjadikan nilai tersebut sebagi sebuah kebiasaan bagi civitas. Namun perlu diperhatikan untuk mengarahkan civitas lembaga pendidikan agar melaksanakan nilai-nilai tersebut maka harus dilengkapi pula infrakstruktur, layanan, dan fasilitas 'menuju' penerapan nilai-nilai organisasi.

Selanjutnya dalam Al-Qur'an memberikan petunjuk pada umat manusia agar dalam suatu wadah, tempat, persaudaraan, ikatan, organisasi, dan kelompok tidak boleh timbul pertentangan, perselisihan, perscekcokkan yang mengakibatkan hancurnya kesatuan, runtuhnya mekanisme kepemimpinan yang telah dibina. Sebagaimana Firman Allah dalam QS al-Anfal [8]: 46 dan QS Ali 'Imran [3]: 103 sebagai berikut:

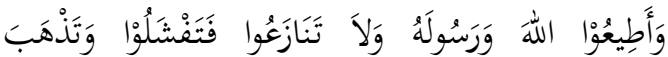

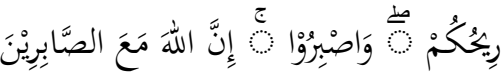

Dan taatilah Allah dan Rasul-Nya, janganlah kamu berbantah-bantahan (berselisih) yang menyebabkan kamu menjadi gentar, hilang kekuatanmu, dan bersabarlah. Sesungguhnya Allah beserta orang-orang yang sabar.

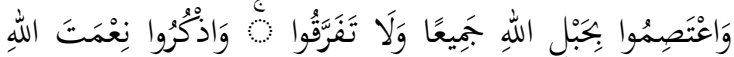

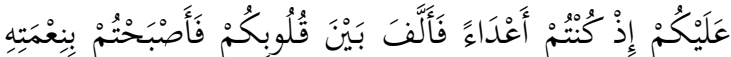

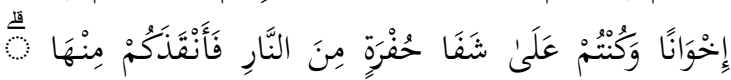

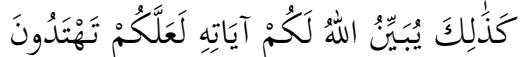

Dan berpeganglah kamu semuanya kepada tali (agama) Allah, dan janganlah kamu bercerai berai, dan ingatlah akan nikmat Allah kepadamu ketika kamu dahulu (masa Jahiliyah) bermusuh-musuhan, Maka Allah mempersatukan hatimu, lalu menjadilah kamu Karena nikmat Allah, orang-orang yang bersaudara; dan kamu Telah berada di tepi jurang neraka, lalu Allah menyelamatkan kamu dari padanya. Demikianlah Allah menerangkan ayatayat-Nya kepadamu, agar kamu mendapat petunjuk Ali 'Imran [3]: 103.

Dari ayat di atas maka dapat dipahami bahwa umat Islam harus memiliki kesatupaduan dalam mencapai sesuatu tujuan terutama untuk melakukan syiar Islam. Dalam konteks ini lembaga pendidikan terutama madrasah merupakan wahana bagi syiar islam. Maka agar lembaga madrasah menjadi unggul di mata masyarakat perlu adanya nilai-nilai organisasi yang ditanamkan agar seluruh personalia atau civitas madrasah.

3) Pembagian kerja, tugas, dan tanggung jawab.

Dalam sebuah organisasi sesuai dengan kapabilatias masing-masing terjemahannya:

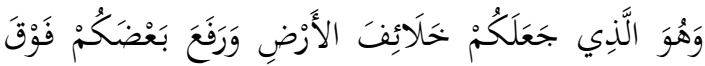

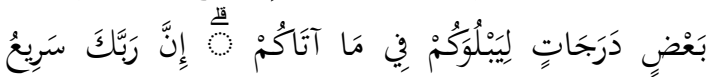

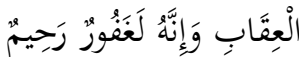

Dan Dia lah yang menjadikan kamu penguasa-penguasa (khalifah) di bumi dan Dia meninggikan sebagian kamu atas sebagian (yang lain) beberapa derajat, untuk mengujimu tentang apa yang diberikan-Nya kepadamu. Sesungguhnya Tuhanmu amat cepat siksaan-Nya dan sesungguhnya Dia Maha Pengampun lagi Maha Penyayang. (QS. al-An'am [6]:165).

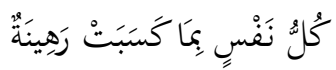

Tiap-tiap diri bertanggung jawab atas apa yang telah diperbuatnya (QS. alMuddatstsir [74]: 38).

Ayat-ayat di atas menjelaskan bahwa setiap manusia dilahirkan di bumi ini dalam status yang sama yaitu hamba Allah namun dalam perkembangannya akan terdapat perbedaan satu sama lain 
sehingga ketika dewasa mereka menjadi sosok orang yang berbeda pula. Ada yang menjadi pemimpin, ada yang dipimpin, ada yang jadi dokter, manajer, pendidik dsb.Namun semuanya pada gilirannya akan diminta pertanggung jawabannya, sesuai dengan peran dan kapasitasnya.

\section{Simpulan}

Manajer dalam memanaj perlu memiliki kompetensi sesuai dengan tuntunan Al-Qur'an, menurut Tanthowi kompetensi tersebut antara lain: Berpengetahuan luas, kreatif, inisiatif, peka, dan lapang dada (QS alMujadalah[58];11), Bertindak adil dan jujur serta konsekuen (QS al-Nisa[4]: 58). Bertanggung Jawab (QS al-An'am[6]: 164). Selektif terhadap informasi (QS alHujurat[49]:6). Memberi petunjuk dan pengarahan (QS al-Sajdah[32]: 24). Sementara manajer juga memiliki Peranan terkait kinerjanya menurut Syaefullah yaitu: Memberikan semangat agar bekerja seefektif dan seefisien mungkin. Mengembangkan perencanaan beserta capaian kinerja manajer memperhatikan keadaan intern dan ekstern yang dihadapkan pada lembaga. Memiliki kemampuan merespon dengan cepat, teliti, dan tepat sasaran dalam menanggapi segala sesuatu yang dapat menguntungkan atau merugikan lembaga pendidikan. Menikmati hasil yang diperoleh dengan berpegang pada etika dan nilai-nilai kelembagaan. Mewujudkan proses pembelajaran yang aktif, inovatif, kreatif, efektif, dan menyenangkan. Menciptakan peserta didik yang mampu mengembangkan dirinya yang mempunyai kekuatan spiritual, pengendalian diri, kepribadian, kecerdasan, akhlak mulia, dan keterampilan yang diperlukan oleh dirinya, masyarakat, dan negara. Menciptkan suasana hubungan harmonis dan terfokus dalam kerja sama antar bidang serta intern bidang pada lembaga pendidikan.
Melaporkan hasil kinerja kemudian ditindaklanjuti dengan pembagian tugas yang imbang sesuai dengan porsi (gaji) masing-masing. Sebagai pembangun nilainilai dalam organisasi sehingga akan memunculkan sosok tertentu sebagai contoh (kemampuan interpersonal). Mulyono menjelaskan selain peran tersebut juga manajer pendidikan dalam pengembangan setiap aspek yang terdapat dalam program kerja pendidikan, terutama adanya tanggung jawab, penjaga nilai-nilai organisasi, pembagian kerja, dan efisiensi.

\section{DAFTAR PUSTAKA}

Abdul Jawwad, M. Ahmad, Manajemen Waktu, (terjemahan Khozin Abu Faqih). Bandung: Syaamil Cipta Media, 2006.

Husaini Usman. Manajemen: Teori, Praktik, dan Riset Pendidikan. Jakarta: Bumi Aksara, 2008.

Ibrahim Bafadal. Seri Manajemen Peningkatan Mutu Pendidikan Berbasis Sekolah. Jakarta: Bumi Aksara, 2009.

Mulyono. Manajemen Administrasi \& Organisasi Pendidikan, Yogyakarta: Ar-Ruzz Media, 2009.

Mulyasa. Manajemen dan Kepemimpinan Kepala Sekolah, Jakarta: Bumi Aksara, 2011.

Muhammad al-Sayyid al-Julayny, al-Imâm Ibn Taymiyyah wa mawqifuhu min qadhiyyât al-ta'wîl, (Kairo: alMaktab al-Amiriyyah, 1973).

Muhammad Abu Zahrah, Ibn Taymiyyah, Hayâtuhu wa Ashruhu, Arâ'uhu wa Fiqhuhu, (Kairo: Dar al-Fikr alArabi, 1974).

Nur Zazin. Gerakan Menata Mutu Pendidikan, Jogjakarta: Ar-Ruzz Media, 2011.

Saefullah. Manajemen Pendidikan 
Islam, (Bandung: Pustaka Setia), 2012.

Rohiat, Manajemen Sekolah: Teori dan Praktik, Bandung: Refika Aditama, 2010.
UU No. 20 Tahun 2003 Tentang Sistem Pendidikan Nasional Bab II Pasal 3, Jakarta: Balitbang, Depdiknas 2004.

Veithza Rivai, Kiat Memimpin Abad 21, (Jakarta: PT Raja Grafindo, 2004) 
